\title{
SWIETŁANA SYDUN
}

Poznań

\section{Partnerstwo Wschodnie - szansa dla europejskiej integracji państw poradzieckich}

Inicjatorami Partnerstwa Wschodniego (PW) są Polska i Szwecja, które w maju 2008 r. zaproponowały pogłębienie relacji ze wschodnimi sąsiadami objętymi Europejską Polityką Sąsiedztwa. Inicjatywa była skierowana do Armenii, Białorusi, Azerbejdżanu, Gruzji, Mołdowy oraz Ukrainy. Rosja zgodziła się uczestniczyć w niektórych wspólnych projektach. Za główne cele Partnerstwa Wschodniego uznano: doprowadzenie do ustanowienia politycznego stowarzyszenia; stworzenie stref wolnego handlu państw partnerskich z UE, liberalizację reżimu wizowego, unifikacje prawną, wzmocnienie współpracy w zakresie bezpieczeństwa energetycznego, wsparcie dla małych i średnich przedsiębiorstw ${ }^{1}$.

W Komunikacie Komisji do Parlamentu Europejskiego i Rady „Partnerstwo Wschodnie” określono, że PW będzie „oparte na wzajemnych zobowiązaniach do przestrzegania zasad państwa prawa, dobrego zarządzania, poszanowania praw człowieka, poszanowania i ochrony mniejszości, a także zasad gospodarki rynkowej i zrównoważonego rozwoju"².

Partnerstwo Wschodnie miało stać się głównym planem rozwoju relacji między Unią a państwami Europy Wschodniej i Kaukazu Południowego. To umożliwia tym państwom stopniowe włączanie się do polityk i programów unijnych oraz integrację ze wspólnym rynkiem, ustanowienie bliższych relacji pomiędzy UE a każdym z państw partnerskich w celu zwiększania stabilności i dobrobytu we wspólnym interesie.

Partnerstwo Wschodnie zostało powołane na szczycie w Pradze w maju 2009 r. W mediach sporo pisano o kolejnej inicjatywie UE, oceniano jej zalety i określano możliwość realizacji propozycji ze strony Unii. Zauważono, że nie wszyscy szefowie państw UE-27 i państw partnerskich byli obecni na szczycie. Nie przybył premier Wielkiej Brytanii Gordon Brown, prezydent Francji Nicolas Sarkozy. Nie byli obecni także szefowie rządów Włoch, Hiszpanii i Austrii. Prezydent Białorusi A. Łukaszenka i prezydent Mołdawii W. Woronin przysłali do Pragi swoich przedstawicieli. Pomimo tego, inicjatywa była przyjęta przez obie strony.

Rosja chłodno przyjęła wiadomość o kolejnej inicjatywie UE dla byłych republik radzieckich, upatrując w tym zagrożenie swych interesów w tym regionie. Unijna komisarz Benita Ferrero-Waldner uspokajała Rosję, że Unia nie ma zamiaru rozszerzać swojej strefy wpływów na kraje byłego Związku Radzieckiego. Głównym argumentem było, że Partnerstwo Wschodnie to inicjatywa dla wzmocnienia polityki sąsiedztwa

1 Komunikat Komisji do Parlamentu Europejskiego i Rady, Partnerstwo wschodnie, Bruksela, dnia 3.12.2008, s. 2.

2 Ibidem, s. 3. 
w tym regionie. Rosja powinna być nastawiona pozytywnie, by w przyszłości zabezpieczyć tam spokój ${ }^{3}$.

Na szczycie rosyjsko-unijnym w Chabarowsku w 2008 r. prezydent Dmitrij Miedwiediew oświadczył, że Unia nie przekonała Rosji, jakie zalety ma PW, a projekt nie powinien być wykorzystany przez niektóre państwa UE przeciwko Rosji ${ }^{4}$. Kilka miesięcy później podczas wizyty w Mińsku, Prezydent Rosji zapewniał białoruskich dziennikarzy, że nie widzi w nowym projekcie UE ani korzyści dla państw partnerskich PW, ani zagrożeń dla Rosyjskiej Federacji ${ }^{5}$. Według rosyjskiego politologa Jurija Solozobowa krytykę PW w Rosji można podzielić na dwa kierunki. Pierwszy - nacjonalistyczny w duchu zimnej wojny, który polega na tym, że Unia chce ustawić sześć byłych republik radzieckich przeciwko Rosji. Drugi powiązany z sektorem energetycznym. Jednym z celów Partnerstwa Wschodniego jest wspieranie unijnego programu energetycznego, który jest sprzeczny z interesami Rosji, innymi słowami, wszystko co jest złe dla Rosniefti i Gazpromu, jest złe dla Rosji ${ }^{6}$.

Michaił Margiełow, przewodniczący komitetu spraw międzynarodowych Rady Federacji, przekonywał, że prawdziwe geopolityczne zamiary Komisji Europejskiej skupiają się na energii, przypominając, że dzień po zakończeniu szczytu w Pradze Komisja zorganizowała specjalne spotkanie, poświęcone gazociaggowi Nabucco. Przyjęcie Ukrainy i Gruzji do NATO zostało odwołane, gdyż projekt PW został zdefiniowany jako próba dołączenia byłych republik radzieckich do strefy wpływów UE okrężną drogą?

Irina Paszkowskaja, pracownik naukowy Centrum Bezpieczeństwa Euro-Atlantyckiego Instytutu Badań nad Stosunkami Międzynarodowymi w Moskwie, wyznaczyła trzy czynniki, pod wpływem których była sformułowana polityka energetyczna UE wobec byłych republik ZSRR: rosnąca zależność UE od importu surowców energetycznych, przesunięcie granic UE do Morza Czarnego po przyjęciu Bułgarii i Rumunii do Unii, osobliwe zainteresowanie Niemców rozszerzeniem swoich stref wpływów w obszarze postradzieckim. Według niej celem podstawowym Unii Europejskiej jest osłabienie swojej zależności od dostaw energetycznych z Rosji ${ }^{8}$.

Jednak inaczej postrzegały Partnerstwo Wschodnie państwa partnerskie. Prezydent Azerbejdżanu Ilham Alijew mówił na szczycie o strategicznym wyborze, jakiego dokonuje jego kraj ${ }^{9}$. M. Saakaszwili, Prezydent Gruzji, przekonywał, że Partnerstwo to

3 Восточное партнерство не направлено на расширение сфер влияния - Ферреро-Вальднер, http://korrespondent.net/ world/829288-vostochnoe-partnerstvo-ne-napravleno-na-rasshireniesfer-vliyaniya-ferrero-valdner, odczyt z dnia 8.09.2011.

4 Евросоюз не убедил Россию в выгодах создания „Восточного партнерства”, http://www.vesti.ru/doc.html?id=286999\&tid=69553, odczyt z dnia 8.09.2011.

5 Медведев пообешал не мешать ЕС развивать „, Восточное партнерство”, http://www.izvestia.ru/news/46236, odczyt z dnia 8.09.2011.

6 Й. Солозобов, Большое „, Восточное партнерство”, http://www.apn.ru/publications/article22423.htm, odczyt z dnia 8.09.2011.

7 Повестка саммита ЕC носит чисто геополитический характер - Маргелов, http://ria.ru/politics/20090507/170289050.html, odczyt z dnia 8.09.2011.

8 I. Paszkowskaja, Европейский Союз: энергетическая политика в отношении новых независимых государств, Москва МГИМО - Университет, 2009, s. 3.

9 Partnerstwo Wschodnie zaczęło się w Pradze, http://wyborcza.pl/1,76842,6583319, Partnerstwo_Wschodnie_zaczelo_sie_w_Pradze.html\#ixzz1NLLrF3mk, odczyt z dnia 15.08.2011. 
efekt zeszłorocznej wojny Rosji z Gruzją i że teraz sześć krajJw siedzi przy stole $\mathrm{z}$ członkami Unii jak równy z równym ${ }^{10}$.

Ukraiński Prezydent Wiktor Juszczenko z zadowoleniem przyjął możliwość uczestnictwa w kolejnej inicjatywie Brukseli, chociaż z lekkim rozczarowaniem, bo kolejna inicjatywa nie przybliżyła jego państwa do spełnienia marzenia o członkostwie w UE ${ }^{11}$. Chociaż podczas spotkania Prezydenta Ukrainy z przewodniczącym Parlamentu Europejskiego Hansem Gertem Poetteringiem w Kijowie, Ukrainie zaproponowano główną rolę we Wschodnim Partnerstwie UE.

Jeszcze przed inauguracją PW, w maju 2009 w Pradze, ówczesny prezydent Mołdawii Władimir Woronin sceptycznie wypowiadał się na temat Partnerstwa Wschodniego, nazywając go „WNP-2” będącym tym razem pod kontrolą nie Rosji, lecz Unii Europejskiej. Krytycznie odnosił się również do zaliczenia Mołdawii do grupy państw, które de facto nie aspirują do wejścia do UE, obok Armenii, Gruzji i Azerbejdżanu ${ }^{12}$.

Prezydent Armenii S. Sarkisjan podziękował UE za inicjatywę Partnerstwa Wschodniego, określając ją mianem odważnej i opartej na zasadzie wzajemnych korzyści. Stwierdził również, że Armenia będzie wywiązywać się z przyjętych zobowiązań w ramach Europejskiej Polityki Sąsiedztwa. Z kolei wiceminister spraw zagranicznych Armenii oświadczyła, że Erewan ma nadzieję, iż jednym z rezultatów współpracy w ramach Partnerstwa Wschodniego będzie podpisanie umowy stowarzyszeniowej między Armenią a UE ${ }^{13}$.

Prezydent A. Łukaszenka oświadczył, że rezultaty szczytu w Pradze są zgodne z oczekiwaniami Białorusi ${ }^{14}$. Oczekiwania te sformułował wicepremier W. Siemaszka, który stał na czele białoruskiej delegacji do Pragi. Znalazły się wśród nich: ułatwienia dla eksportu na rynek unijny, możliwość pozyskania inwestycji i kredytów, możliwość pełniejszego wykorzystania tranzytowego położenia Białorusi, w tym budowy gazociagu Jamał II oraz perspektywa liberalizacji reżimu wizowego dla Białorusinów. Przez rok Prezydent Białorusi krytykował Partnerstwo Wschodnie za to, że UE wymaga od Białorusi udziału przedstawicieli opozycji w Zgromadzeniu Parlamentarnym Partnerstwa Wschodniego - Euronest, a od innych krajów - nie. A. Łukaszenka uważa także, że Unia Celna z Rosją dała i daje więcej korzyści dla Białorusi, niż Partnerstwo Wschodnie ${ }^{15}$.

Kraje, objęte projektem PW są zróżnicowane pod względem rozwoju gospodarczego i politycznego. Wspólnym dla tych państw jest spuścizna sowiecka, zależność od Rosyjskiej Federacji i przynależność do jej strefy wpływów, a także korupcja, powolne tempo wprowadzenia reform, niski rozwój gospodarczy.

Najwyższy wskaźnik PKB wśród państw, objętych PW, jest w Azerbejdżanie (jak widać z tabeli 1), co wyjaśnia się posiadaniem wielu złóż ropy naftowej przez to pań-

10 Ibidem.

11 Б. Соколовський, Ініціатива „Східне партнерство” не підміняє ідеї набуття Украӥною повноцінного членства в СC, http://www.president.gov.ua/news/13699.html, odczyt z dnia 10.08.2011.

12 Partnerstwo Wschodnie a kwestia Mołdawii, http://www.psz.pl/tekst-27624/Partnerstwo-Wschodnie-a-kwestia-Moldawii, odczyt z dnia 15.05.2011.

${ }_{13}$ Reakcje na szczyt inauguracyjny Partnerstwa Wschodniego, „Tydzień na Wschodzie” 2009, nr 8, s. 12, http://www.osw.waw.pl/sites/default/files/tnw93.pdf, odczyt z dnia 10.05.2011.

${ }_{14}$ Reakcje na szczyt inauguracyjny, op. cit., s. 7.

15 Александр Лукашенко раскритиковал „, Восточное партнерство, http://news.open.by/politics/38791, odczyt z dnia 14.09.2011. 
stwo. Ukraina jest największym krajem, ale i z bardzo niskim PKB, chociaż posiada rudy żelaza, węgiel kamienny, rudy manganu (jedne z największych zasobów na świecie), a także gaz ziemny, ropę naftową (których wydobycie pozwala na pokrycie około 20-30\% krajowego zapotrzebowania). Metalurgia ma około 20\% udziału w strukturze produkcji przemysłowej Ukrainy (ósme miejsce na liście największych producentów stali na świecie) ${ }^{16}$.

Najbiedniejszym państwem jest Mołdawia, z wysoką stopą bezrobocia i mało rozwiniętym przemysłem. Kraj eksportuje produkty rolno-spożywcze. Zgodnie z raportem Banku Światowego „Migration and Remittances Factbook 2011”, przekazy pieniężne stanowią aż 23\% PKB Mołdowy i w tym rankingu kraj znalazł się na 4 miejscu na świecie ${ }^{17}$. Armenia w tym rankingu znajduje się na 26 miejscu (9\% PKB). Warto zaznaczyć, że w Mołdawii kilka lat wcześniej (w 2006 r.) ten wskaźnik stanowił 36\%, a w Armenii - 18\% ${ }^{18}$.

Główny udział w tworzeniu PKB Republiki Białorusi ma produkcja przemysłowa, najważniejsze są przemysły: paliwowy, chemiczny oraz elektromaszynowy, a także rolnictwo. Większość przedsiębiorstw jest własnością państwową. Jedynym sektorem w Republice Białoruś, w którym przeważa własność prywatna są handel i usługi.

Według „Corruption Perceptions Index 2010” Transparency International najmniej skorumpowanym krajem jest Gruzja (tabela 1). Taki wynik związany jest z wprowadzonymi przez Prezydenta Saakaszwilego reformami w instytucjach władzy i administracji publicznej. Pozostałe kraje zajmują miejsca w drugiej setce. Polepszyła się w rankingu pozycja Azerbejdżanu (ze 158 do 134), Białorusi (ze 151 do 127) i Mołdawii (ze 109 do 105). Sytuacja pozostaje niezmienną na Ukrainie - miejsce 134 (chociaż w 2006 roku zajmowała miejsce 99).

Tabela 1

Wskaźniki rozwoju krajów, objętych Partnerstwem Wschodnim i Rosji (2010 r.)

\begin{tabular}{|c|c|c|c|c|c|c|c|}
\hline \multirow[t]{2}{*}{ Kraj } & \multirow{2}{*}{$\begin{array}{l}\text { Ludność } \\
\text { mln osób }\end{array}$} & \multirow{2}{*}{$\begin{array}{c}\text { PKB } \\
\text { mld euro }\end{array}$} & \multirow{2}{*}{$\begin{array}{c}\text { PKB } \\
\text { per capita }\end{array}$} & \multicolumn{2}{|c|}{$\begin{array}{l}\text { Ranking Corruption } \\
\text { Perceptions Index }\end{array}$} & \multicolumn{2}{|c|}{$\begin{array}{c}\text { Ranking Democracy } \\
\text { Index }\end{array}$} \\
\hline & & & & 2008 & 2010 & 2008 & 2010 \\
\hline Armenia & 3,3 & 7,1 & 2146,6 & 109 & 123 & 113 & 109 \\
\hline Azerbejdżan & 9,0 & 41,0 & 4532,1 & 158 & 134 & 135 & 135 \\
\hline Białoruś & 9,4 & 41,3 & 4375,4 & 151 & 127 & 130 & 132 \\
\hline Gruzja & 4,4 & 8,8 & 2005,0 & 67 & 66 & 103 & 104 \\
\hline Mołdowa & 3,6 & 4,4 & 1229,8 & 109 & 105 & 65 & 62 \\
\hline Ukraina & 45,5 & 102,9 & 2262,7 & 134 & 134 & 67 & 53 \\
\hline Rosja & 140,4 & 1105,1 & 7873,2 & 147 & 154 & 107 & 107 \\
\hline
\end{tabular}

Źródło: Opracowanie własne na podstawie danych z http://ec.europa.eu/trade/statistics/, http://www.transparency.org/policy_research/surveys_indices/cpi, http://graphics.eiu.com/PDF/Democracy_Index_2010_web.pdf.

16 Informator ekonomiczny o krajach świata. Ukraina, http://www.msz.gov.pl/files/Informator\%20ekonomiczny\%20-\%20pdf/Ukraina/Ukraina\%2003.pdf, odczyt z dnia 23.09.2011.

17 Migration and Remittances Factbook 2011, http://siteresources.worldbank.org/INTLAC/Resources/Factbook2011-Ebook.pdf, 23.09.2011.

18 Migration and Remittances Factbook 2008, http://www-wds.worldbank.org/external/default/ WDSContentServer/IW3P/IB/2008/03/14/000333038_20080314060040/Rendered/PDF/429130PUB0 Migr101OFFICIAL0USE0ONLY1.pdf, odczyt z dnia 23.09.2011. 
Corocznie agencja „Economist Intelligence Unit” przygotowuje raport o stanie demokracji w 167 krajach. Wskaźnik demokracji jest średnią ważoną na podstawie odpowiedzi na 60 pytań, które dotyczą wolności i sprawiedliwości wyborów, bezpieczeństwa wyborców, wpływu obcych mocarstw na politykę rządową zdolności urzędników do wprowadzania regulacji prawnych w życie. Także agencja proponuje klasyfikacje dla krajów według rankingu: demokracje pełne, demokracje wadliwe, systemy hybrydowe i reżimy autorytarne.

Mołdowa i Ukraina są państwami o demokracji wadliwej. Stan demokracji na Ukrainie pogorszył się, co może być związane z przejęciem władzy przez nowego Prezydenta Ukrainy ze swoją ekipa. Sytuacja w Mołdawii powoli się poprawia. To wynika z tego, że Kiszyniów jest pozytywnie nastawiony do europejskiej integracji. Rosja, Armenia i Gruzja są państwami o reżimach hybrydowych. Po rewolucji róż w Gruzji nastapiła tam demokratyczna transformacja, ale obserwatorzy z zewnątrz wskazują na wiele wad w funkcjonowaniu demokracji.

Białoruś i Azerbejdżan są państwami autorytarnymi, ze słabo rozwiniętą opozycją, kontrolowanymi przez władze media i organizacje społeczeństwa obywatelskiego. Konsekwencją tego jest sytuacja, w której w ramach rankingu ze 167 uczestników te państwa znajdują się prawie na końcu.

Stosunki handlowe UE-27 z krajami, objętymi PW i Rosją (2010 r.)

\begin{tabular}{||l|c|c|c|c||}
\hline \multicolumn{1}{|c|}{ Kraj } & $\begin{array}{c}\text { Import UE } \\
\text { mIn euro }\end{array}$ & $\begin{array}{c}\text { Miejsce } \\
\text { w rankingu }\end{array}$ & $\begin{array}{c}\text { Export UE } \\
\text { mIn euro }\end{array}$ & $\begin{array}{c}\text { Miejsce } \\
\text { w rankingu }\end{array}$ \\
\hline Armenia & 259,0 & 107 & 556,7 & 101 \\
\hline Azerbejdżan & 9763,5 & 29 & 2346,8 & 56 \\
\hline Białoruś & 2627,3 & 54 & 6715,7 & 34 \\
\hline Gruzja & 558,0 & 82 & 1155,3 & 74 \\
\hline Mołdowa & 581,9 & 81 & 1528,3 & 66 \\
\hline Ukraina & 11396,9 & 25 & 17334,7 & 3 \\
\hline Rosja & 158384,9 & 3 & 86508,8 & 3 \\
\hline
\end{tabular}

Źródło: Opracowanie własne na podstawie danych z http://ec.europa.eu/trade/statistics/.

Unia Europejska jest głównym partnerem handlowym państw objętych Partnerstwem Wschodnim (tabela 3). Te państwa nie są tak ważne dla Unii Europejskiej. Stosunki handlowe najlepiej rozwijają się z Ukrainą i Azejbardżanem (według statystyki, tabela 2). Rosja zajmuje trzecie miejsce jako strategiczny handlowy partner UE. Z Azerbejdżanu UE importuje produkty z kategorii paliwa i produkty górnictwa (ich udział w imporcie - 99,2\%), a z Ukrainy - wyroby metalurgiczne, artykuły rolno-spożywcze, produkty mineralne, artykuły przemysłu chemicznego. $Z$ pozostałych krajów - Armenii, Gruzji, Białorusi i Mołdowy - Unia Europejska importuje produkty rolno-spożywcze, produkty przemysłowe.

W strukturze eksportu Unia Europejska a państwa partnerskie PW dominowały maszyny i urządzenia, produkty chemiczne i tworzywa sztuczne, artykuły rolno-spożywcze, środki transportu. Dla Białorusi najważniejszym partnerem pozostaje Rosja, która 
ma prawie połowę udziału w handlu zewnętrznym tego państwa (tabela 3). Dla Mołdowy, Azerbejdżanu i Gruzji ważniejszym partnerem jest UE niż Rosja. Udział w handlu między RF a Mołdową i Gruzją drastycznie zmniejszył się w ciągu ostatnich lat, głównie poprzez wprowadzone przez Moskwę sankcje gospodarcze wobec tych państw.

Tabela 3

Stosunki handlowe krajów, objętych PW z UE-27 i Federacją Rosyjską

\begin{tabular}{||l|c|c|c|c|c|c|c|c||}
\hline \multicolumn{1}{|c|}{ Kraj } & $\begin{array}{c}\text { Import w UE } \\
\text { mln euro }\end{array}$ & $\mathbf{\%}$ & $\begin{array}{c}\text { Import w FR } \\
\text { mIn euro }\end{array}$ & $\mathbf{\%}$ & $\begin{array}{c}\text { Export w UE } \\
\text { mIn euro }\end{array}$ & \% & $\begin{array}{c}\text { Export w FR } \\
\text { mIn euro }\end{array}$ & \% \\
\hline Armenia & 780,9 & 27,9 & 629,9 & 22,1 & 379,2 & 49,0 & 121,2 & 15,9 \\
\hline Azerbejdżan & 2437,6 & 34,1 & 1009,6 & 14,1 & 8391,1 & 52,6 & 703,7 & 4,4 \\
\hline Białoruś & 6069,5 & 24,3 & 13249,2 & 53,1 & 4410,1 & 26,3 & 6866,5 & 40,9 \\
\hline Gruzja & 1211,1 & 30,0 & 223,9 & 5,5 & 497,1 & 36,7 & 14,1 & 1,0 \\
\hline Mołdowa & 1646,1 & 53,5 & 289,4 & 9,4 & 527,3 & 48,9 & 22,4 & 20,6 \\
\hline Ukraina & 15782,5 & 35,2 & 14505,8 & 32,4 & 9942,1 & 26,7 & 8630,9 & 23,2 \\
\hline Rosja & 87979,7 & 50,2 & & & 136056,6 & 44,8 & & \\
\hline
\end{tabular}

Źródło: Opracowanie własne na podstawie danych z http://ec.europa.eu/trade/statistics/.

Znaczna część gospodarki w państwach, objętych PW jest kontrolowana przez administrację państwowa, a większość dużych przedsiębiorstw sprywatyzowanych należy do inwestorów z Rosji. Pod szczególnie silnym nadzorem pozostaje sektor energetyczny, w którym znaczne udziały ma Rosja. Sektor energetyczny Azerbejdżanu znajduje się pod bezpośrednim nadzorem prezydenta i jego rodziny. Wzajemna finansowa, biznesowa i polityczna zależność ludzi biznesu oraz parlamentarzystów i polityków rządowych jest charakterystyczna dla gospodarek WNP.

Pod względem społecznym sytuacja na Kaukazie Południowym i Europie Wschodniej jest również trudna. Znaczna część ludności żyje poniżej progu ubóstwa, różnice dochodów bogatych i ubogich dramatycznie rosną, sytuacje komplikuje wysokie bezrobocie i migracja zarobkowa.

UE w ramach projektu Partnerstwa Wschodniego postawiła kilka głównych celów. Jednym z nich jest podpisanie umowy o stowarzyszeniu z państwami nieczłonkowskimi. Taka umowa przewiduje przyjęcie zobowiązań przez państwo partnerskie do realizacji reform politycznych, gospodarczych, handlowych albo reform w dziedzinie praw człowieka. Ze swojej strony UE zobowiązuje się pozwolić tym krajom korzystać z preferencyjnego dostępu do niektJrych lub wszystkich rynków UE, jak również udzielać pomocy finansowej i technicznej.

Celem takich umów jest utworzenie szeroko zakrojonej i kompleksowej strefy wolnego handlu z każdym z krajów partnerskich. Strefy te mogą być tworzone dopiero po przystapieniu państw do WTO. Białoruś i Azerbejdżan nie są członkami organizacji, chociaż negocjacje w tej sprawie trwają już kilka lat. Natomiast Armenia uczestniczy w WTO od 2003 roku, Mołdawia - od 2001 r., Gruzja - od 2000 r., Ukraina - od 2008 r. Przewiduje się, że Azerbejdżan dołączy do WTO w ciagu 2-3 lat, w wypadku Białorusi ten proces może potrwać dłużej. 
Przewiduje się, że strefy wolnego handlu obejmą jego wszystkie gałęzie, łącznie $z$ energią. Będą one zawierać wiążące prawnie zobowiązania w sprawie harmonizacji ustawodawstwa w obszarach związanych $\mathrm{z}$ handlem i tym samym przyczyniać się do modernizacji gospodarek krajów partnerskich oraz ugruntowania niezbędnych reform gospodarczych. W dłuższym okresie stworzą rzeczywiste perspektywy zwiększonego przepływu towarów, kapitału i świadczenia usług ${ }^{19}$.

Pierwszym krajem, z którym może zostać zawarta Umowa o Stowarzyszeniu, jest Ukraina. Umowa o stowarzyszeniu będzie określać nie tylko prawne stosunki Ukrainy i Unii Europejskiej, lecz także pobudzać Ukrainę do społecznych i gospodarczych reform. Dokument przewiduje współpracę stron w różnych obszarach. Jej podstawą jest jednak obszar gospodarczy, który bazować będzie na strefie wolnego handlu.

Negocjacje na temat umowy stowarzyszeniowej między Ukrainą a UE trwają trzy lata. Było przeprowadzono prawie 20 rund negocjacyjnych. W kwietniu 2011 r. w Kijowie odbyła się XVI runda negocjacji w sprawie utworzenia strefy wolnego handlu pomiędzy Unią Europejską a Ukrainą. Podsumowując wyniki rozmów przedstawiciele obu stron podkreślili, iż na dzień dzisiejszy 90\% zagadnień dotyczących utworzenia strefy wolnego handlu została już uzgodniona, w tym uzgodniono zniesienie wszelkich ograniczeń taryfowych i ilościowych w odniesieniu do eksportu 96\% pozycji towarowych z Ukrainy do krajów członkowskich Unii Europejskiej (w tym wszystkich towarów przemysłowych). Do zagadnień spornych zaliczyć należy kwestię zaprzestania wykorzystywania przez producentów ukraińskich w nazwach swoich towarów geograficznych nazw miejscowości innych krajów opatentowanych przez producentów unijnych, rozwiązywania sporów w sektorze energetycznym, wprowadzania ceł eksportowych przez Ukrainę, ochrony ukraińskiego sektora produkcji samochodów oraz kwestie związane z przewozami samochodowymi. Pomimo szeregu pozostających do uzgodnienia kwestii, przewodniczący grupy negocjacyjnej Komisji Europejskiej P. Cuisson ocenia, iż porozumienie o strefie wolnego handlu Unia Europejska-Ukraina zostanie podpisane do końca 2011 r. (podczas prezydencji Polski w Radzie UE) i może wejść w życie w 2013 r. po ratyfikacji dokumentu przez strony oraz wypełnieniu przez Ukrainę wszystkich wymogów UE. Przewodniczący P. Cuisson również wyraził nadzieję, iż za 10 lat Ukraina całkowicie włączona zostanie w europejską gospodarkę ${ }^{20}$.

Podpisaniu Umowy o stowarzyszeniu Ukrainy i UE sprzeciwia się Rosja. Moskwa zaprasza Kijów do Unii Celnej. Ukraina po podpisaniu Umowy z Unią ma szanse rozwijać się jako demokratyczne i suwerenne państwo, polepszyć stan swojej gospodarki i życie społeczeństwa. Natomiast powrót do Rosji może spowodować jeszcze większe uzależnienie Ukrainy od tego kraju, co w konsekwencji może doprowadzić do przekształcenia jej w państwo autorytarne i zacofane.

Przyszła umowa stowarzyszeniowa z Ukrainą jest w trakcie przygotowań. Umowy z pozostałymi państwami Partnerstwa Wschodniego będą podobne ${ }^{21}$. W Preambule będą określone główne cele dokumentu, a także może zostać wyrażona wola Unii do

19 Komunikat Komisji..., op. cit., s. 10.

20 У Європі чекають повної інтеграиії Украӥни за 10 років, http://www.epravda.com.ua/ news/2011/02/15/271495/view_print/, odczyt z dnia 15.05.2011.

21 S. Ananicz, Umowy stowarzyszeniowe..., op. cit., s. 2. 
nadania państwu stowarzyszonemu statusu członka. Jednak w przypadku negocjowanych umów z państwami partnerskimi takiego postanowienia najprawdopodobniej nie będzie. Następny rozdział - Dialog polityczny i współpraca w sprawach zewnętrznych - określi cel dialogu zagranicznego, a mianowicie, zasadę poszanowania niepodległości, suwerenności, terytorialnej integralności i nienaruszalności granic. Wyznacza też reguły działań dotyczących regionalnej stabilności, zapobiegania konfliktom, zarządzania kryzysowego, przeciwdziałania rozprzestrzenianiu się broni masowego rażenia, kwestii rozbrojenia i kontroli zbrojeń, walki z terroryzmem i innych. Rozdział - Obszar wolności, bezpieczeństwa i sprawiedliwości - będzie dotyczyć współdziałania, a także wzajemnych zobowiązań w kwestiach praworządności, przestrzegania praw człowieka, ochrony danych osobowych, migracji, polityki azylowej i zarządzania granicami, przepływu osób, zwalczania prania brudnych pieniędzy i finansowania terroryzmu, zwalczania handlu narkotykami, zwalczania korupcji i przestępczości.

Umowa obejmie także współpracę gospodarczą i sektorową, która dotyczyć będzie wzajemnych zobowiązań w takich kwestiach, jak: rolnictwo i rozwój obszarów rolnych, polityka audiowizualna, społeczeństwo obywatelskie, dostosowanie prawa o działalności gospodarczej do standardów UE, ochrona konsumentów, współpraca transgraniczna i regionalna, współpraca w obszarze kultury i edukacji, współpraca w energetyce, w kwestiach środowiska, rybołówstwa, ochrony czystości wód, opieki zdrowotnej, turystyki, transportu i innych.

Z Armenią, Gruzją i Mołdawią negocjacje na temat podpisania umów stowarzyszeniowych rozpoczęto w $2010 \mathrm{r}$. i już przeprowadzono po kilka rund negocjacji. Z Białorusią nie rozpoczęto żadnych negocjacji. To państwo angażuje się głównie we współpracę w ramach Państwa Związkowego Rosji i Białorusi oraz Unii Celnej Białoruś-Rosja-Kazachstan. Stosunki UE i Białorusi pozostają napięte. W czerwcu 2011 roku w odpowiedzi na rosnące represje na Białorusi, UE zdecydowała o zamrożeniu aktywów trzech firm finansujących reżim Alaksandra Łukaszenki. Zamrożenie aktywów dotyczyło produkującej broń firmy Biełtiecheksport, która handlowała m.in. z reżimem libijskiego przywódcy Muammara Kadafiego i komunistyczną Koreą Północną, a także firmy hazardowej Sport-Pari (filia krajowego Superlotto) oraz telekomunikacyjnego przedsiębiorstwa Biełtieliekom ${ }^{22}$.

Celem partnerstwa jest zwiększenie bezpieczeństwa energetycznego UE i jej państw partnerskich pod względem długoterminowych dostaw i tranzytu energii. Komisja Europejska zaproponowała kilka środków dwustronnych, w ramach drugiego strategicznego przeglądu sytuacji energetycznej ${ }^{23}$ :

- uwzględnienie w umowach o stowarzyszeniu postanowień dotyczących „współzależności energetycznej” $\mathrm{w}$ zgodzie z unijną polityką handlową i energetyczną oraz polityką konkurencji, w sprawie których z państwami partnerskimi przeprowadzone zostaną negocjacje;

- zawarcie protokołów ustaleń w kwestiach energetycznych z Mołdawią, Gruzją i Armenią jako dodatkowych elastycznych instrumentów; powinny one zawierać środki

${ }^{22}$ Nowe sankcje UE wobec Białorusi, w tym gospodarcze, http://www.gazetaprawna.pl/wiadomosci/artykuly/524916, nowe_sankcje_ue_wobec_bialorusi_w_tym_gospodarcze.html, odczyt z dnia 20.09.2011.

23 Kominikat Komisji..., op. cit, s. 8. 
służące do wspierania i monitorowania bezpieczeństwa dostaw i tranzytu energii, również dla kluczowej infrastruktury energetycznej (w przypadku Armenii protokół uzgodnień dotyczyłby również kwestii zamknięcia elektrowni atomowej w Mecamor);

- bliższe stosunki polityczne z Azerbejdżanem, który jest jedynym państwem partnerskim eksportującym węglowodory do UE, w oparciu o stopniową konwergencję Azerbejdżanu z rynkiem energetycznym UE oraz integrację infrastrukturalna;

- zawarcie deklaracji energetycznej między Komisją Europejską a Białorusią jako podstawa dalszego rozwoju współpracy energetycznej, współpraca ta mogłaby obejmować m.in. reformę przesyłu węglowodorów i sektora energetycznego;

- zachęcanie wszystkich państw partnerskich do udziału w programie Inteligentna Energia - Europa.

Azejbardżan posiada istotne zasoby surowców energetycznych. Pozostałe państwa partnerskie PW są zależne od dostaw rosyjskich, chociaż przez terytorium niektórych przebiegają gazociagi z Rosji do UE. Przez terytorium Gruzji przebiegają rurociagi z Azejberdżanu do Turcji. Tranzyt surowców energetycznych jest atutem dla byłych republik radzieckich w stosunkach z Rosją, co prowadzi do sporów i konfliktów politycznych. Przykładem jest wojna gazowa pomiędzy Ukrainą i Rosją. Także warto wspomnieć o sporach związanych z udziałem w sektorze energetycznym Białorusi pomiędzy Mińskiem i Moskwą. Rosja przez kilka lat prowadziła negocjacje o 100\% udziału swego Gazpromu w Beltransgazie i w listopadzie 2011 roku jej to udało się ${ }^{24}$.

Ukraiński system gazowy jest jednym z największych w Europie Wschodniej i składa się z 39,8 tys. km gazociagów. Ukraińskie gazociągi związane z gazociagami państw sąsiedzkich - Rosji, Białorusi, Polski, Słowacji, Węgier, Rumunii i Mołdowy. Ukraina związana z systemem gazowym UE jest mostem pomiędzy największymi wydobywcami gazu ziemnego w świecie - Rosją i Azją Centralną. Przez Ukrainę przepływa $80 \%$ zasobów gazu ziemnego, z czego $20 \%$. przypada na kraje Unii ${ }^{25}$. Białoruskie gazociągi są mniejsze w porównaniu z Ukrainą - 7,5 tys. km i związane z Litwą, obwodem Kaliningradzkim, Polską i Ukrainą ${ }^{26}$.

UE podpisała z Azerbejdżanem w Baku na początku 2011 roku porozumienia o dostępie Europy do gazu z basenu Morza Kaspijskiego. Pierwszy raz Azerbejdżan zobowiązał się na piśmie dostarczać Europie „znaczące ilości gazu”, a także zaangażować się $\mathrm{w}$ budowę infrastruktury dla takich dostaw ${ }^{27}$. W UE z zadowoleniem przyjęto porozumienie z Azerbejdżanem, gdyż jest to szansa na zmniejszenie zależności od Gazpromu.

Budowa gazociagu Nabucco ma rozpocząc się w 2013 r., a od 2017 r. rurociagiem tym ma popłynąć gaz z rejonu Morza Kaspijskiego (Azerbejdżanu, Iraku i Turkmenistanu) przez Turcję, Rumunię i Bułgarię, do Europy Środkowej. Terminy realizacji były wielokrotnie przekładane z różnych przyczyn. Rosjanie chcą dostarczać swoim

\footnotetext{
24 Россия дала Белоруссии газ, а она ей „Белтрансгаз”, http://ria.ru/politics/20111125/ 498024813.html, z dnia 25.11.2011.

${ }_{25}$ Газотранспортна система Украӥни, http://www.ukrexport.gov.ua/ukr/prom/ukr/19.html, odczyt w dniu 20.03.2011.

26 Транзитный транспорт российского газа, http://www.btg.by/transit_transport.html, odczyt z dnia 23.09.2011.

27 UE uzgadnia dostawy gazu z Azerbejdżanu, omijajac Rosję, http://wyborcza.biz/biznes/ 1,101562, 8945756,UE_uzgadnia_dostawy_gazu_z_Azerbejdzanu_omijajac.html, odczyt z dnia 23.09.2011.
} 
gazociagiem South Stream gaz od końca 2015 roku, kiedy będzie gotowa jedna z jego planowanych czterech nitek, co pozwoli zaopatrywać południową część Europy. Gazociąg ma prowadzić z Rosji do Bułgarii, gdzie podzieli się na dwie nitki: północną - do Austrii i Słowenii przez Serbię i Węgry oraz południową - do Włoch przez Grecję. Rosyjskiemu projektowi sprzeciwia się Turcja.

W lutym $2011 \mathrm{r}$. Ukraina notyfikowała ratyfikację protokołu akcesyjnego, stając się tym samym jej pełnoprawnym członkiem. Przystapienie Ukrainy do Wspólnoty spowodowało dla niej pewne trudności, przede wszystkim dla państwowej spółki gazowej NAK „Naftogaz Ukrainy”, która zgodnie z zasadami UE podzielona ma być na 3 odrębne spółki: wydobywczą, dystrybucyjną i transportującą. Ponadto w ciagu 7 lat Ukraina zobowiązana jest do przeprowadzenia kosztownej modernizację systemu energetycznego i mocy produkcyjnych. Niestety, Ukraina nie dysponuje całą kwotą niezbędną do dostosowania systemu energetycznego do norm europejskich. Wartość nakładów na modernizację ukraińskiego systemu transportu gazu według różnych ocen ekspertów wynosi od 5,5 do 15 mld USD.

Kwestia modernizacji ukraińskiego systemu przesyłu gazu ziemnego jest obiektem rozmów władz Ukrainy z potencjalnymi inwestorami (w tym z krajów Unii Europejskiej i Federacji Rosyjskiej). Jednym z największych inwestorów na Ukrainie jest Europejski Bank Odbudowy i Rozwoju. Priorytetem w inwestowaniu jest sektor energetyczny. Dla EBOR ważne są projekty dotyczące kredytowania spółek, transportujących ropę naftową przez Morze Czarne, podwyższenie energooszczędności, rozwój przemysłu.

W marcu 2011 roku w czasie konferencji Instytutu Adama Smitha „Ukraińskie Energetyczne Forum" EBOR zaproponowało zainwestownie około 500 mln USD rocznie w ukraiński sektor energetyczny. Według słów dyrektora zarządzającego ds. Energetyki Banku R. Puliti ${ }^{28}, 1 / 3$ tych środków mogłaby trafić do poszczególnych spółek energetycznych w zamian za przejęcie przez Europejski Bank Odbudowy i Rozwoju udziałów w tych spółkach, a pozostała kwota - w postaci długoterminowych kredytów. EBOR gotowy jest inwestować w okresie 7-10 lat, chociaż zwykle projekty, które są finansowane przez Bank, trwają 5-7 lat. Puliti zauważył, że dla wzmożenia efektywności inwestycji w ukraiński sektor energetyczny niezbędne jest udoskonalenie bazy prawnej państwa.

Unia Europejska proponuje państwom, objętym PW, współpracę w zakresie bezpieczeństwa, co obejmuje walkę z nielegalną imigracją dostosowanie systemów azylowych do standardów UE, utworzenie zintegrowanych systemów zarządzania granicami dostosowanych do zapisów dorobku prawnego UE, a także podwyższanie zdolności policji i wymiaru sprawiedliwości, przede wszystkim w zakresie walki z korupcją i przestępczością zorganizowaną.

Na obszarze WNP obowiązuje bezwizowy ruch. Układy o mobilności i bezpieczeństwie opracowywane są indywidualnie w oparciu o potrzeby poszczególnych krajów, co ma zwiększyć mobilność obywateli, jednocześnie przyczyniając się do zwiększenia stabilności i bezpieczeństwa partnerów, jak również bezpieczeństwa granic z UE.

28 Р. Пуліті, СБРР може вкладати 500 млн євро щорічно в енергетичні проекти в Украӥні, http://www.rbc.ua/ukr/top/show/r-puliti-ebrr-mozhet-vkladyvat-500-mln-evro-ezhegodno-v-energet icheskie-02032011125100, odczyt w dniu 28.04.2011. 
Podejście do polityki wizowej ma charakter etapowy i docelowo prowadzi do liberalizacji reżimu wizowego na specjalnych warunkach. Umowom o ułatwieniach wizowych powinny towarzyszyć umowy o readmisji oraz, w razie potrzeby, pomoc techniczna w ramach ogólnych budżetów pomocy w celu ułatwienia państwom partnerskim wypełnienia zobowiązań wynikających z tych umów. Przewiduje się, że po wprowadzeniu w życie umów o ułatwieniach wizowych i readmisji, należy rozpocząć dialog ze współpracującymi państwami partnerskimi na temat zniesienia obowiązku wizowego. Chociaż ta perspektywa jest bardzo daleka.

W 2009 r. zakończyły się negocjacje umowy o ułatwieniach wizowych UE z Gruzją (takie umowy obowiązują już w relacjach z Ukrainą i Mołdowa). Jednocześnie trwają intensywne rozmowy nad wypracowaniem form współpracy na tym obszarze z Armenią i Azerbejdżanem.

Podczas XIV Szczytu Ukraina-UE w Brukseli jednym z głównych tematów był plan działań na rzecz zniesienia krótkoterminowych wiz pobytowych dla obywateli Ukrainy w państwach strefy Schengen. Przyjęto Plan Wizowy, który określa wszystkie warunki, które musi spełnić Ukraina, by możliwe było zlikwidowanie obowiązku wizowego. Janukowycz obiecał, że spełni warunki do końca 2011 roku, już przed Euro 2012, ale przywódcy unijni nie byli tak optymistycznie nastawieni. Plan wizowy nie zawierał żadnych dat i w Unii Europejskiej trwa spór o to, jak szybko włączyć Ukrainę do wspólnej strefy bezwizowej.

Polska i Wegry naciskają na szybkie otwarcie granic UE dla UkraińcJw, ale Francja i Niemcy są temu bardzo niechętni. Główne przyczyny - ryzyko, że Ukraina stanie się państwem tranzytowym dla nielegalnych migrantów z innych państw poradzieckich do UE i sprzeciw Rosji, która nigdy nie wybaczyłaby UE, że wizy najpierw zostały zniesione dla Ukraińców. To samo można powiedzieć i o innych państwach, objętych projektem PW. Warto pamiętać, że Rosyjska Federacja jest trzecim najważniejszym partnerem handlowym UE (po USA i Chinach). Umowy o ułatwieniach wizowych i readmisji zostały podpisane z Ukrainą, Gruzją i Mołdawią. W wypadku pozostałych państw trwają przygotowania do negocjacji.

W ramach projektu Partnerstwa Wschodniego UE zaproponowała pomoc finansową. Na realizację PW Komisja Europejska postanowiła przeznaczyć $600 \mathrm{mln}$ euro ponad środki już przewidziane w budżecie 2007-2013 na bilateralną współpracę UE z jej sąsiadami w ramach Europejskiej Polityki Sąsiedztwa (EPS) - 12 mld euro na całą EPS na lata 2007-2013, w tym np. na Ukrainę 494 mln euro do 2010 roku. Jak podkreśliła Ferrero-Waldner, z tych dodatkowych $600 \mathrm{mln}$ euro tylko $350 \mathrm{mln}$ to nowe środki z tzw. marginesu w ramach rubryki na politykę sąsiedzką i stosunki zewnętrzne. $250 \mathrm{mln}$ euro KE chce wyasygnować ze środków na regionalne programy w ramach EPS na Wschodzie ${ }^{29}$.

Partnerstwo Wschodnie przewiduje także dodatkowe źródła finansowania. Państwa uczestniczące w Partnerstwie zwróciły się do Europejskiego Banku Inwestycyjnego (EBI), Europejskiego Banku Odbudowy i Rozwoju i innych międzynarodowych organizacji finansowych o kredytowe wsparcie wspólnych działań. EBI wyraził zainteresowanie uczestnictwem w projektach dotyczących głównych obszarów działalności

${ }^{29}$ Komunikat Komisji.., op. cit., s. 12. 
Banku: w sektorach transportu, energii, telekomunikacji i infrastruktury środowiskowej. Wsparcie otrzymają także małe i średnie przedsiębiorstwa. Oprócz tego, dodatkowe fundusze mogą być przekazane przez poszczególne państwa członkowskie UE i/lub kraje trzecie zainteresowane wspieraniem wybranych projektów Partnerstwa Wschodniego.

Największą pomoc otrzymała Ukraina - 470,0 mln euro. Inne państwa - Azerbejdżan - 122,5 mln euro, Armenia - 157,0 mln euro, Gruzja - 180,30 mln euro (dodatkowa pomoc 500 mln euro po wojnie rosyjsko-gruzińskiej), Mołdawia - 273,1 mln euro ${ }^{30}$.

Pierwsze nieformalne spotkanie Ministrów Spraw Zagranicznych państw UE i państw, objętych projektem Partnerstwa Wschodniego, organizowane wspólnie przez Polskę, odbyło się w Sopocie w maju 2010 r. W ramach spotkania podsumowano największe osiagnięcia $\mathrm{PW}^{31}$ :

- projekt zintegrowanego zarządzania granicami (Integrated Border Management) z pulą środków w wysokości $50 \mathrm{mln}$ euro;

- prace nad przygotowaniem programu wspierania małej i średniej przedsiębiorczości (57 mln euro na lata 2010-2013), pierwszym krokiem w realizacji tego programu było uruchomienie projektu East-Invest ( $7 \mathrm{mln}$ euro), którego celem jest poprawienie klimatu inwestycyjnego w państwach partnerskich oraz utworzenie sieci kontaktów biznesowych pomiędzy UE i jej wschodnimi sąsiadami;

- inicjatywę Zapobiegania Katastrofom Naturalnym i Spowodowanym przez Człowieka (6 mln euro);

- przyszłe uruchomienie programu wymiany informacji dot. ochrony środowiska Environment Governance (1,8 $\mathrm{mln}$ ) oraz programu kulturalnego PW (12 mln euro);

- Inicjatywę ds. Zwiększenia Wydajności Energetycznej i Ochrony Środowiska w Europie Wschodniej z budżetem 1,5 mld euro.

Europejski Bank Inwestycyjny stworzył instrument finansowania projektów w ramach PW (Eastern Partners Facility 1,5 mld euro), przeznaczony na inwestycje infrastrukturalne w państwach partnerskich PW i uzupełniający dotychczasowy mandat zewnętrzny EBI na inwestycje w regionie Europy Wschodniej (3,7 mld euro).

Szereg organizacji międzynarodowych współpracuje w ramach PW. Rada Europy podjęła działania na rzecz udziału w programach PW zwalczających korupcję oraz w działaniach na rzecz usprawnienia systemów sądownictwa. OBWE planuje podjęcie współpracy w ramach podnoszenia standardów ochrony praw człowieka. EBOR i OECD są zaangażowane w program wspierania małej i średniej przedsiębiorczości we wschodnich państwach partnerskich.

Duże zainteresowanie PW wykazały organizacje pozarządowe z UE i państw partnerskich. W grudniu 2009 r. w Brukseli odbyło się pierwsze posiedzenie Forum Społeczeństwa Obywatelskiego PW. Wzięło w nim udział około 200 organizacji pozarządowych. Forum powołało Komitet Sterujący, który koordynuje działania NGOs z UE i krajów partnerskich. Prace Forum mają na celu pobudzenie współpracy pomię-

30 S. Ananicz, Umowy stowarzyszeniowe jako cel Partnerstwa Wschodniego, ,Infos” 2011, nr 9, s. 3.

31 Nieformalne spotkanie Ministrów Spraw Zagranicznych nt. Partnerstwa Wschodniego, http://polandeu.gov.pl/files/Aktualnosci/konferencja_WHO_IS_WHO_24.05.2010.pdf, odczyt dnia 2.05.2011. 
dzy społeczeństwami i wzmocnienie obywatelskiego aspektu działań PW. Kolejne spotkanie forum odbędzie się w Polsce w listopadzie $2011 \mathrm{r}$.

W końcu września 2011 roku odbył się szczyt Partnerstwa Wschodniego, na który przyjechało 32 delegacje państw członkowskich Unii Europejskiej i państw partnerskich oraz przedstawiciele najważniejszych instytucji UE. Niestety, nie było delegacji z Mińska. Na szczyt nie zaproszono Prezydenta Białorusi Aleksandra Łukaszenki, czym poczuł się bardzo obrażony, a także ograniczony został udział w szczycie wyznaczonego przez Republikę Białorusi jej przedstawiciela. Ambasada Republiki Białorusi opublikowała komunikat, w którym skrytykowała Szczyt, wskazując, że ,partnerstwo nie może się opierać na dyskryminacji”, a organizatorzy Szczytu ,poprzez swoje działania szkodzą sprawności tej regionalnej inicjatywy i ponoszą za to odpowiedzialność" 32 .

Premier Polski Donald Tusk w swoim wystąpieniu powiedział, że „,we współpracy ze środowiskami obywatelskimi na Białorusi wypracowaliśmy taktykę postępowania, która nie jest ingerencją w wewnętrzne sprawy Białorusi, jest tylko klarownym komunikatem: możliwa jest wydatna pomoc przy modernizacji Białorusi, ale ta wydatna pomoc, która może iść w miliardy euro, będzie możliwa wobec demokratycznego partnera, Białoruś musi spełnić warunki, żeby oferta mogła być zrealizowana”. Mińsk powinien spełnić pewne warunki, między innymi, przeprowadzić demokratyczne wybory parlamentarne zgodnie ze standardami OBWE, zacząć dialog polityczny z opozycją, a także ogłosić amnestię i rehabilitację więźniJw politycznych ${ }^{33}$.

Kilka dni później Minister Spraw Zagranicznych Białorusi Siergiej Martynow oświadczył, ,że Białoruś ma zamiar nadal uczestniczyć w programach Partnerstwa Wschodniego. Białoruś razem z Litwą i Ukrainą zaproponowała ponad 20 konkretnych projektów. Trwa poważna praca ekspertów w zakresie współpracy celnej, energetycznej, zwalczania kiberprzestępczości i korupcji. Partnerstwo jest korzystne dla Białorusi”,34 .

Kolejnym państwem, które było krytykowane za prześladowania opozycji ze względów politycznych, była Ukraina. Miało to wpływ na podpisanie Umowy Stowarzyszeniowej pomiędzy Ukrainą a UE. We wspólnej Deklaracji Warszawskiego Szczytu Partnerstwa Wschodniego przyjęto, że sfinalizowanie negocjacji w tej sprawie możliwe będzie do czasu szczytu UE-Ukraina w grudniu 2011 r. $^{35}$

Uczestnicy szczytu potwierdzili, że wiele zrobiono w czasie istnienia Partnerstwa Wschodniego. Państwa partnerskie wdrożyły reformy polityczne i gospodarcze, a stosunki między UE i jej wschodnioeuropejskimi partnerami uległy znacznemu pogłębieniu. UE i większość jej partnerów zaangażowało się w negocjacje dotyczące Umów Stowarzyszeniowych, które doprowadzą także do utworzenia Pogłębionych i Kom-

32 Oświadczenie Ministerstwa Spraw Zagranicznych ws. Szczytu Partnerstwa Wschodniego w Warszawie, http://www.poland.belembassy.org/pl/news/ page_m12=1 news_m12=214224, odczyt $\mathrm{z}$ dnia 5.10.2011.

33 Szczyt Partnerstwa Wschodniego bez Białorusi, http://fakty.interia.pl/raport/polska-prezydencja-w-ue/news/szczyt-partnerstwa-wschodniego-bez-bialorusi, 1701881,7580, odczyt z dnia 5.10.2011.

34 Minister Spraw Zagranicznych Białorusi o Partnerstwie Wschodnim, http://www.poland.belembassy.org/pl/news/ page_m12=1 news_m12=215314, odczyt z dnia 5.10.2011.

35 Wspólna Deklaracja Warszawskiego Szczytu Partnerstwa Wschodniego, Warszawa, 29-30 września 2011, http://www.msz.gov.pl/files/docs/komunikaty/20110930EAP/Wspolna\%20Deklaracja\%20Warszawskiego\%20Szczytu\%20Partnerstwa\%20Wschodniego.pdf, s. 3, odczyt z dnia 5.10.2011. 
pleksowych Stref Wolnego Handlu (DCFTA), gdy tylko spełnione zostaną odpowiednie warunki. Jednocześnie zaangażują się w zwiększanie mobilności na całym kontynencie. Rozpoczęto dialog z Ukrainą i Republiką Mołdowy w sprawie zniesienia obowiązku wizowego. Wdrożone zostały umowy z Gruzją o ułatwieniach wizowych i readmisji, a podobne mają w przyszłości być zawarte także z Republiką Armenii, Republiką Azerbejdżanu i Republiką Białorusi ${ }^{36}$.

Partnerstwo Wschodnie wprowadziło do dotychczasowego modelu stosunków z państwami Kaukazu Południowego i Europy Wschodniej kilka ważnych zmian. Głównym atutem jest wyodrębnienie wschodnich sąsiadów od południowych i wprowadzenie wschodniego sąsiedztwa w orbitę polityki zagranicznej UE jako osobnej grupy. Dotychczas EPS obejmowało jednakowym mechanizmem zarówno państwa Europy Wschodniej, jak i kraje Afryki Północnej i Bliskiego Wschodu, co powodowało wiele dyskusji jak w UE, tak i wśród wschodnioeuropejskich sąsiadów.

Krytyka Partnerstwa Wschodniego dokonywana przez państwa partnerskie dotyczy małej sumy na finansowanie projektów w ramach PW. Uważają oni, że UE nie jest zainteresowana kolejnym rozszerzeniem na Wschód. UE krytykuje państwa wschodnie za opieszałość w reformach i wykonaniu zobowiązań. Ważnym jest także to, że UE z dystansem traktuje państwa takie jak: Armenia, Azerbejdżan, Białoruś, Mołdowa, Gruzja i Ukraina, byłe republiki radzieckie o małym dla Unii znaczeniu gospodarczym. Widząc, że należą one do strefy wpływów Rosji, Unia nie chce podejmować bezpośredniej rozgrywki politycznej.

Mimo krytyki, Partnerstwo Wschodnie jest ważną płaszczyzną dla rozwoju stosunków między UE i państwami Europy Wschodniej i Południowego Kaukazu. Zaplanowano wiele projektów w ramach tej inicjatywy, kilka z nich już uruchomiono. O sukcesie Partnerstwa Wschodniego zadecyduje przede wszystkim wola polityczna oraz zdolności państw członkowskich UE i państw partnerskich do skutecznej realizacji tych projektów. Na wyniki realizacji projektów PW trzeba będzie poczekać.

\section{Summary}

\section{Eastern Partnership - A chance for European integration of post-soviet states}

Eastern Partnership - a new EU initiative. While it is difficult to say what benefits it will bring to both parties: Azerbaijan, Armenia, Belarus, Georgia, Moldova, Ukraine and EU countries. Of course, now more critical than results. Partner countries pose a different problem in the implementation of its relationship with EU, but they all share a common desire to deepen these relations. The EU should be open in this matter and to offer a higher level of political organizations, and progressive strengthening of ties in key areas. It takes time to appreciate the influence of the EU on the development of partner countries of Eastern Partership. But we must remember that the result depends on both sides.

\footnotetext{
36 Ibidem, s. 1.
} 